\title{
Preservation of the intangible cultural heritage through the implementation of additional general education programs in the field of \\ fine arts
}

\author{
Preservação do patrimônio cultural imaterial por meio da \\ implementação de programas de educação geral adicional na área de \\ belas artes
}

\section{Preservación del patrimonio cultural inmaterial mediante la implementación de programas adicionales de educación general en el campo de las bellas artes}

\author{
Irina Vladimirovna Lovtsova ${ }^{1}$ (D) , Lyudmila Aleksandrovna Burovkina² (D), \\ Anna Sergeevna Sheshko ${ }^{3}$
}

\footnotetext{
${ }^{1}$ All-Russian Center for the Development of Artistic Creativity and Humanitarian Technologies, Russian Federation .

${ }^{2}$ Moscow City Pedagogical University, Russian Federation.

${ }^{3}$ Child Development Center - Kindergarten, Russian Federation.
}

\section{Corresponding author:}

Irina Vladimirovna Lovtsova

Email: i.v.lovtsova@yandex.ru

\begin{abstract}
How to cite: Lovtsova, I. V., Burovkina, L. A., \& Sheshko, A. S. (2021). Preservation of the intangible cultural heritage through the implementation of additional general education programs in the field of fine arts. Revista Tempos $e$ Espaços em Educação, 14(33), e15929. http://dx.doi.org/10.20952/revtee.v14i33.15929
\end{abstract}

\begin{abstract}
The problem of preserving the traditions of academic art and folk culture as part of the intangible cultural heritage of the country is becoming more urgent every year. One of the solutions to this problem is the transfer of knowledge and technology using additional general education programs. Implementation of additional general education programs reveals the practical possibilities of children's creativity and shows the effectiveness of forms and methods for preserving the intangible cultural heritage through the practical development of techniques and technologies of artistic creation by children, which are based on academic or folk traditions. This, in the authors' opinion, introduces the scientific novelty of this study. The theoretical basis of pedagogical mastery is studied and the need for a competency-based approach in the implementation of additional education programs on the example of the experience of children's art schools is shown. In addition, the study substantiates the need for the effective construction of educational and methodological support for educational programs, the actualization and development of teacher's competencies, as well as the preservation and development of methods containing the basic principles and technologies of the
\end{abstract}


academic foundations of fine arts and folk crafts. Proposals to organize support for the implementation of additional general education programs in the field of fine and decorative arts and folk crafts are made.

Keywords: Academic art. Folk crafts. Teacher. Arts and crafts. Children's art schools.

\section{RESUMO}

O problema de preservar as tradições da arte acadêmica e da cultura popular como parte do patrimônio cultural imaterial do país está se tornando mais urgente a cada ano. Uma das soluções para esse problema é a transferência de conhecimento e tecnologia por meio de programas adicionais de educação geral. A implementação de programas de educação geral adicionais revela as possibilidades práticas da criatividade das crianças e mostra a eficácia de formas e métodos para preservar o patrimônio cultural imaterial por meio do desenvolvimento prático de técnicas e tecnologias de criação artística por crianças, que são baseadas em tradições acadêmicas ou folclóricas. Isso, na opinião dos autores, apresenta a novidade científica deste estudo. A base teórica do domínio pedagógico é estudada e é mostrada a necessidade de uma abordagem baseada em competências na implementação de programas educacionais adicionais no exemplo da experiência das escolas de arte para crianças. Além disso, o estudo consubstancia a necessidade da construção efetiva de suportes pedagógicos e metodológicos para os programas educacionais, a atualização e o desenvolvimento das competências do professor, bem como a preservação e o desenvolvimento de métodos que contenham os princípios básicos e tecnologias dos fundamentos acadêmicos da multa. artes e ofícios populares. São apresentadas propostas para organizar o apoio à implementação de programas adicionais de educação geral no domínio das artes finas e decorativas e do artesanato popular.

Palavras-chave: Arte acadêmica. Artesanato popular. Professor. Artes e Ofícios. Escolas de arte para crianças.

RESUMEN: El problema de preservar las tradiciones del arte académico y la cultura popular como parte del patrimonio cultural inmaterial del país es cada año más urgente. Una de las soluciones a este problema es la transferencia de conocimientos y tecnología mediante programas adicionales de educación general. La implementación de programas adicionales de educación general revela las posibilidades prácticas de la creatividad de los niños y muestra la eficacia de las formas y métodos para preservar el patrimonio cultural inmaterial mediante el desarrollo práctico de técnicas y tecnologías de creación artística por parte de los niños, que se basan en tradiciones académicas o populares. Esto, en opinión de los autores, introduce la novedad científica de este estudio. Se estudia la base teórica del dominio pedagógico y se muestra la necesidad de un enfoque basado en competencias en la implementación de programas de educación adicional sobre el ejemplo de la experiencia de las escuelas de arte para niños. Además, el estudio fundamenta la necesidad de la construcción efectiva de apoyos educativos y metodológicos para los programas educativos, la actualización y desarrollo de las competencias docentes, así como la preservación y desarrollo de métodos que contengan los principios básicos y tecnologías de los fundamentos académicos de la fina educación. artes y artesanías populares. Se hacen propuestas para organizar el apoyo a la implementación de programas adicionales de educación general en el campo de las artes plásticas y decorativas y la artesanía popular.

Palabras clave: Arte académico. Artesanías populares. Profesor. Artes y manualidades. Escuelas de arte para niños. 


\section{INTRODUCTION}

One of the important problems of modern society is the problem of revising the education system, the compliance of teachers with professional competencies and the search for new solutions and modern approaches to organizing the learning process, including teaching fine arts.

The education system in the field of art and culture is an integral part of all education in the Russian Federation and has its own history, traditions and structural features. Undoubtedly, education, including art education, should carry fundamental knowledge, new ideas and proposals to use new trends and technologies - "a new time requires a new dominant" (Christiansen, 1911, p. 209).

Modern art education in Russia is carried out in academies, universities, institutes, secondary specialized educational institutions, children's art schools and other educational organizations.

\section{LITERATURE REVIEW}

The problem of preserving the fundamental foundations of culture in the field of art education is reflected in the works of scholars in the field of psychology, philosophy, pedagogy and methodology of fine arts. R. Arnheim (2007), N. N. Volkov (2012), D. I. Feldshtein (1994), E. P. Ilin (2009), V. D. Shadrikov (2002) discussed this issue within the framework of psychology. In the field of philosophy, various issues of culture, art and artistic creativity were studied by V. V. Vanslov (1989) and B. T. Likhachev (1985). The issues of the organization of educational activity and artistic and aesthetic development of the personality were studied by K. Zh. Amirgazin (1995), L. A. Burovkina (2011), S. E. Ignatiev (2007), V. V. Koreshkov (1994), V. S. Kuzin (1998), S. P. Lomov (2011), A. A. Prishchepa (2013), N. N. Rostovtsev (2000), S. P. Roshchin (2013) and others. "The nature, specificity and depth of children's creativity have been studied for centuries" (Prishchepa et al.: 2019, p. 346).

Today, in general, higher and secondary education institutions, a system of additional education for children, in which children's art schools play a key role, represent the education system in the field of art and culture of the Russian Federation. "The special goals and objectives of children's art schools require uniform approaches in the country to assess the quality of the implementation of educational activities, as well as educational activities related to them" (Arakelova, 2012, p. 6).

Currently, due to the efforts of scientists, heads of educational institutions and teachers, Russian Academy of Arts, higher education institutions, art schools and centers for additional education for children are the guardians of centuries-old world culture. Today, additional education of children is a part of a continuing education system designed to provide a child with additional opportunities for intellectual, spiritual and physical development, as well as the satisfaction of their creative and educational needs (Burovkina, 2010c).

A particularly important task of modern art education in the field of fine arts is the preservation of the academic art school, the development of arts and crafts and the preservation of the traditions of national crafts and cultural values of folk art.

Preservation of the traditions of folk crafts has an educational, spiritual and moral aspect. "It has been noticed that the world of man-made objects (household utensils, clothes, fabrics, toys), which a child meets from the beginning of their life, evokes a lively response from them, activates creative thought, promotes the development of artistic knowledge, helps answer many questions" (Burovkina, 2010a, p. 36).

The transfer of knowledge to a new generation takes place in close interconnection with artproduction workshops, colleges and individual masters - craftsmen and bearers of traditions in the family. The hypothesis of the study is that the use of effective forms and methods for the practical development by children of techniques and technologies of artistic creation, which are based on 
academic or folk traditions, will contribute to the preservation of the intangible cultural heritage, its development and translation.

\section{METHODS}

To study the pedagogical experience of additional education teachers, the system of children's art schools was examined, and the learning process in educational organizations in various regions was analyzed. In particular:

- Children's Art School named after M. Chagall, Togliatti, Samara Oblast, Russia;

- Children's Art School No. 3 named after E. V. Gurov, Omsk, Russia;

- Children's Art School No. 2 of Arts and Crafts named after V. D. Polenov, Tambov, Russia. As a result, practical ways of preserving the traditions of academic art and folk culture were studied (Figs. 1-3) and the importance of improving the professional competencies of teachers was revealed.

Figure 1. The works of students of the Children's Art School named after M. Chagall

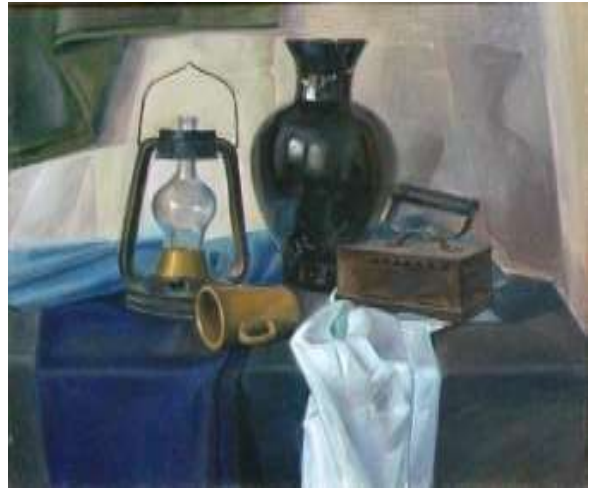

Ekaterina Sokolova, 16 y. o.

Teacher; Shepilova N. lu.

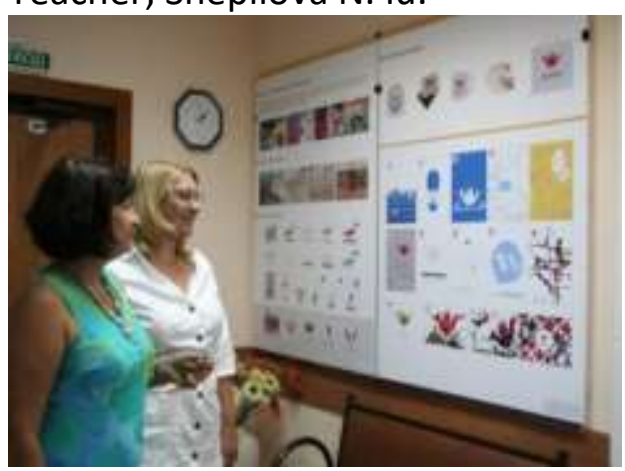

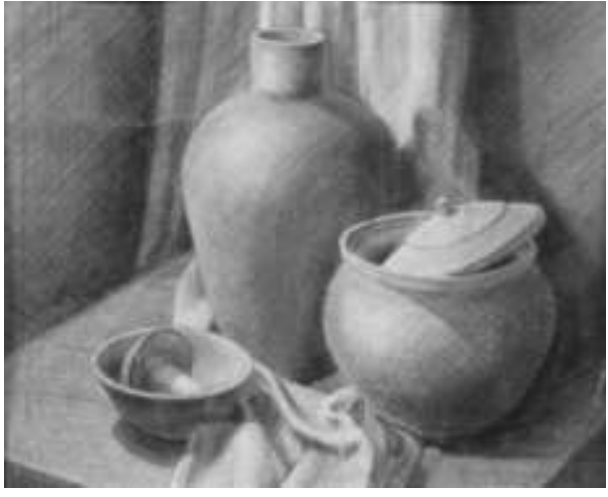

Ekaterina Karamalikova, 15 y. o.

Teacher: Zubkov N. A.

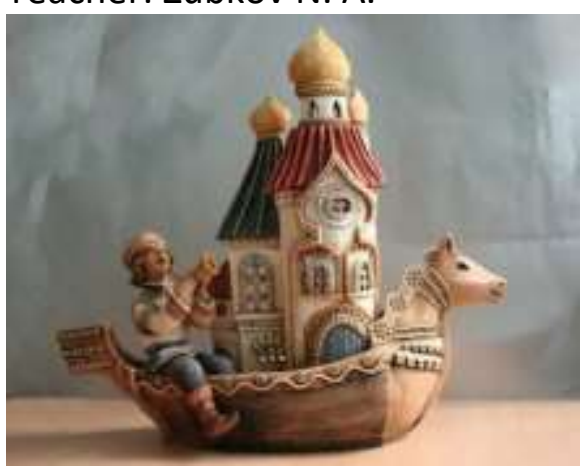

Daria Dobridnik, 14 y. o.

Teacher: Zamula I. V. 
Figure 2. The works of students of the Children's Art School No. 3 named after E. V. Gurov, Omsk

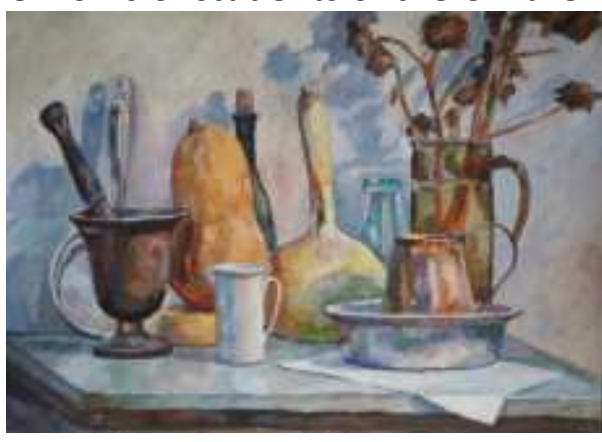

Vika Gromova, 15 y. o.

Teacher: Tkalich E. A.

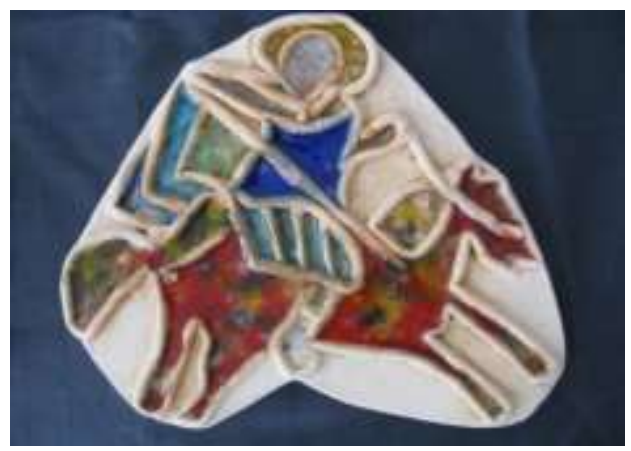

Lilia Fedorchenko, 12 y. o.

Teacher: Gorchakov S. A.

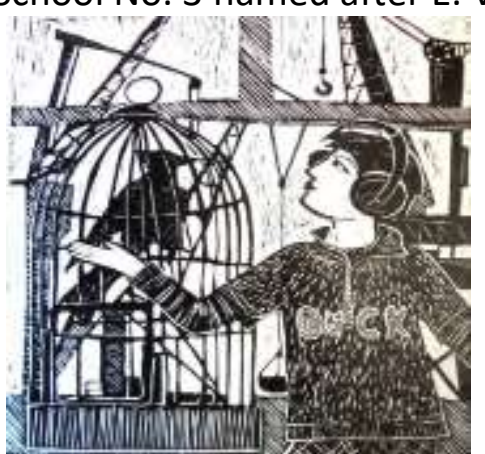

Mariia Usoltseva, 13 y. o.

Teacher: Tkalich E. A.

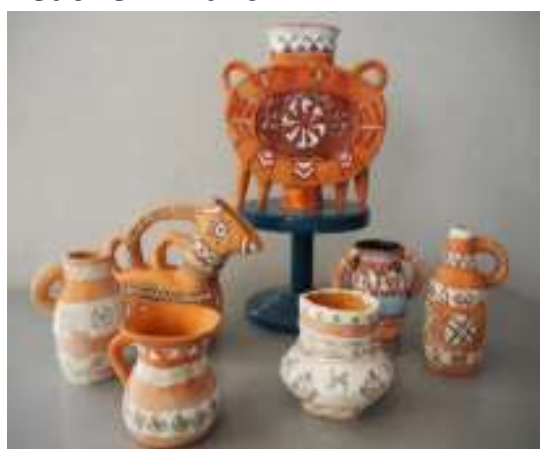

Groupwork on decorative ceramics jug, 12-13 y. o.

Teacher: Gorchakov S. A.

Figure 3. The works of students of the Children's Art School of Arts and Crafts No. 2 named after V. D. Polenov, Tambov
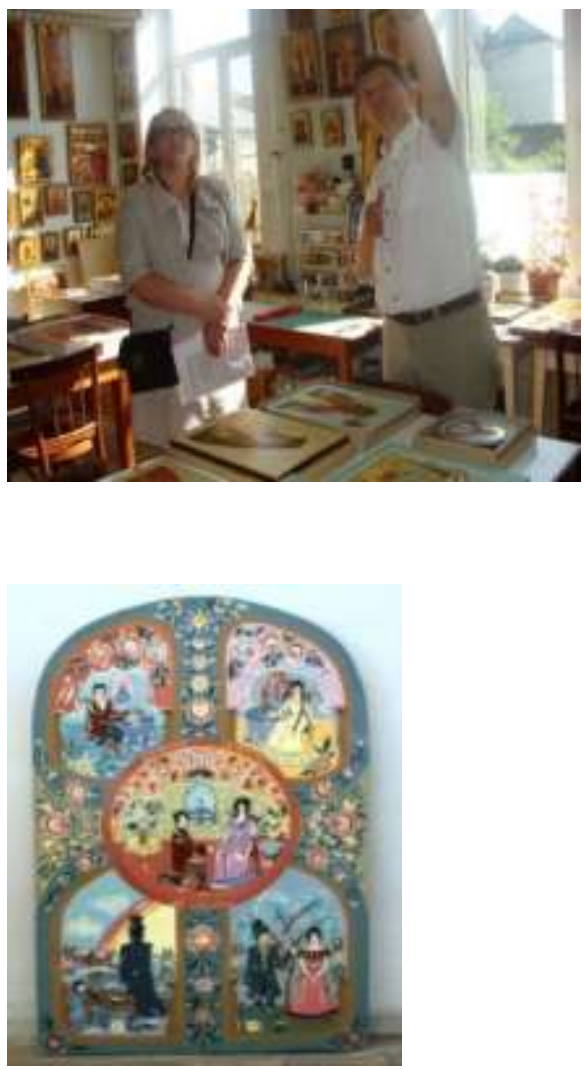

L. Bliznetsova, 15 y. o.

Teacher: Rogozhkina L. S.

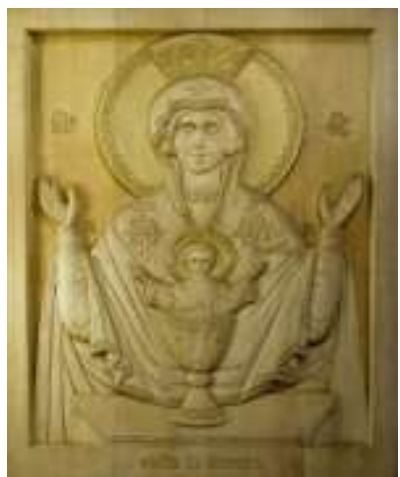

R. Ivannikov, 17 y. o.Teacher: Nikokskii M. V.

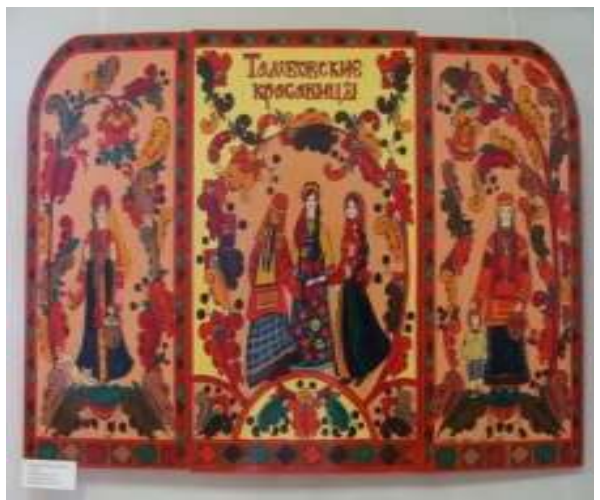

O. Anosova, 16 y. o.

Teacher: Rogozhkina L. S. 
A special role in the transfer of skill and traditions and the upbringing of young artists and masters belongs to additional general education programs and especially to teachers. It is no secret that many modern children are "suppressed by the media that bears a low culture and lack of spirituality" (Roshchin, 2010, p. 64). To fulfill their mission, teachers must have broad competencies and be professional in the field of art, pedagogy, cultural studies and psychology of education.

The actualization of competencies is a transition from awareness of opportunities and potentialities to actions.

Teachers constantly improve their scientific and methodological potential and are engaged in experimental and innovative activities, ensuring the modernization and development of the education system in the field of culture.

Professional knowledge and competencies in today's rapidly changing world are losing relevance and require correlation with technological changes and socioeconomic transformations (Burovkina: 2010b).

The goal of a modern, effective "education system is to form creativity to ensure the formation of the innovative potential of the nation" (Zimniaia, 2003b, p. 12). The potential, which should be built on innovation and tradition, as well as the search for new and respect for the knowledge and experience of ancestors.

Implementation of additional education programs is impossible without educational and methodological support, namely: teaching programs, thematic educational and methodological manuals, didactic, informational and reference materials, special and methodological literature, etc.

When listening to the numerous speeches of leaders and teachers or visiting organizations of additional education for children, it is often possible to ascertain the insufficient provision of the educational process with educational and methodological materials. In this regard, "the need arose for the theoretical development of special techniques" for teaching fine and decorative art that meet modern requirements for the educational process (Nalivaiko, Petrov, 2001, p. 4).

The duties of a teacher include the selection of methodological and visual material. They need to ensure that the visual material is consistent, including the visual art used in the educational process (Zimniaia, 2003a).

Teachers must introduce modern multimedia materials into the educational process. Children should have access to printed or electronic reference books, be able to navigate and quickly use various sources of information. In addition, teachers need to possess the skills of using computer technology and knowledge of databases in the taught field (Fig. 4-6).

The applied materials must meet the modern conditions of a dynamically changing world and focus on changes in the information society and the individual needs and capabilities of children.

Figure 4. Educational and visual materials of the Children's Art School named after M. Chagall
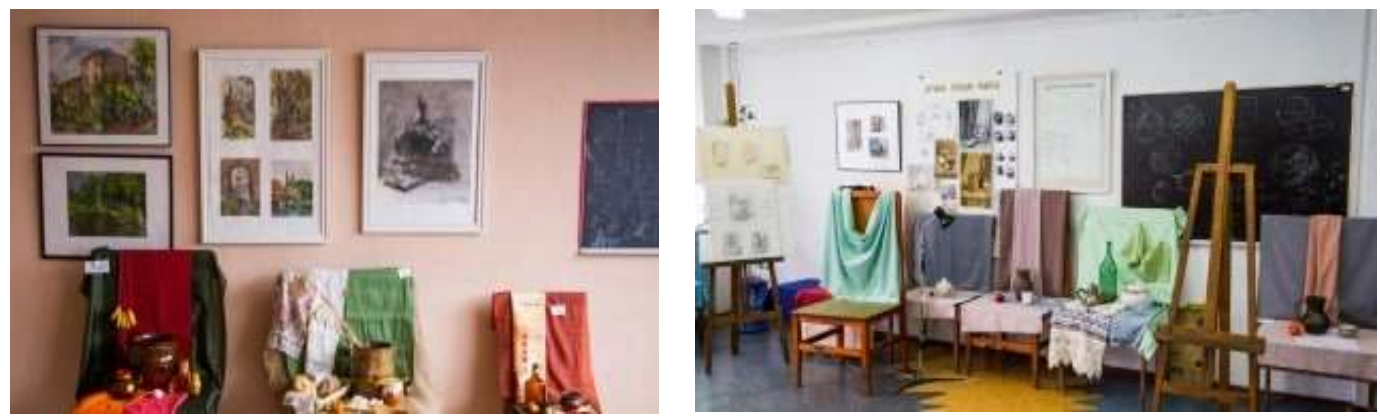
Figure 5. Educational and multimedia materials of the Children's Art School No. 3 named after E.
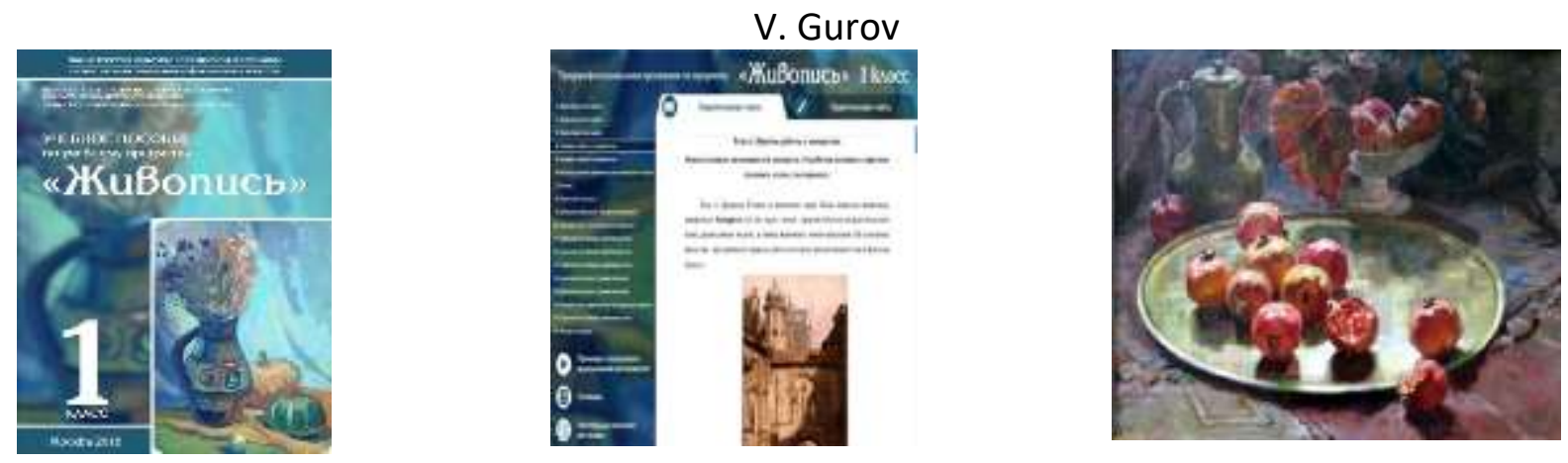

Figure 6. Educational and multimedia materials of the Children's Art School of Arts and Crafts No.

2 named after $V$. D. Polenov

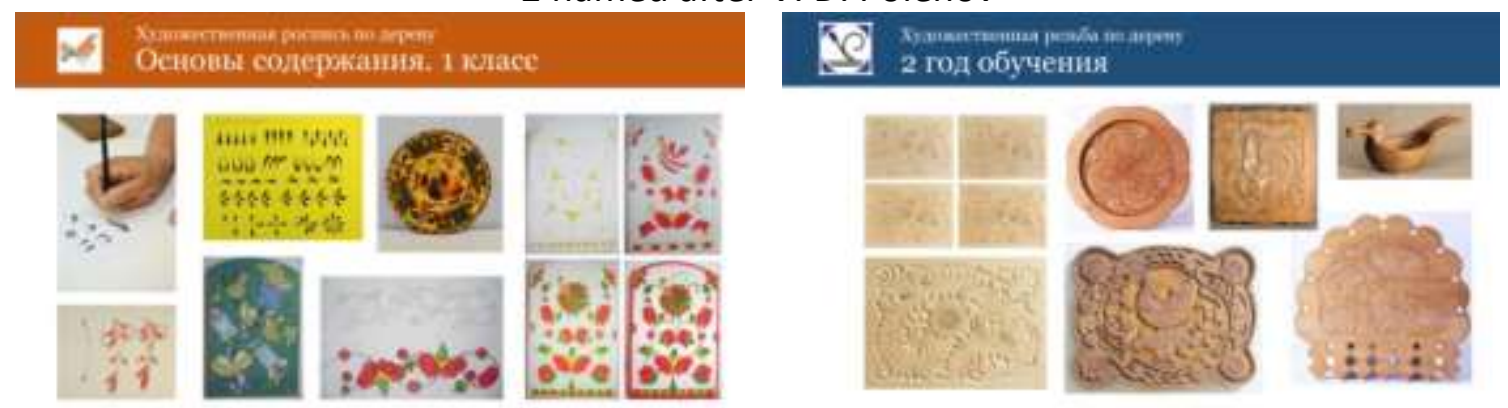

Худажестиеннан резьба по дерену

Мультимедиа материалы
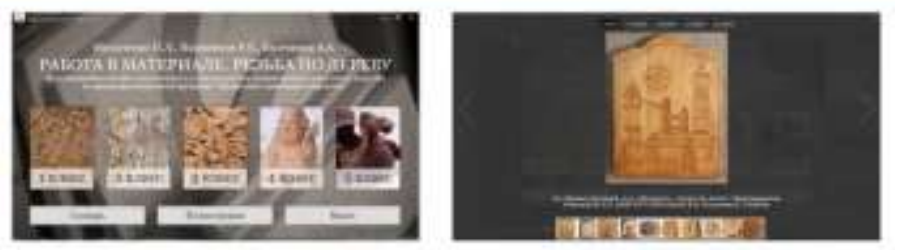

Changes in history and science as well as the style and pace of society's life, are connected with the development of the teacher's competencies. Therefore, a system of updating and improving them is necessary. This requires an effective system of professional development of teachers and competent work of methodological services at all levels: from methodologists and methodological services to the regional and federal levels.

However, teachers also need to strive for updating knowledge and skills, self-improvement and personal and professional growth.

In the system of art education, there is no standard for additional education of children, only state requirements for additional prevocational programs; there are no developed or approved textbooks and teaching manuals.

It is necessary to form and record the content of educational material in print and electronic media. There is an urgent need for the introduction of modern forms of translation of educational material based on the positions of correspondence with the present, systematic, based on the principles of preserving academic and folk traditions. Visual material should provide maximum information for students about the type of folk art craft considered (Fig. 7-10). 
Figure 7. Dymkovo toy. Ways to perform sculpting (Visual material)

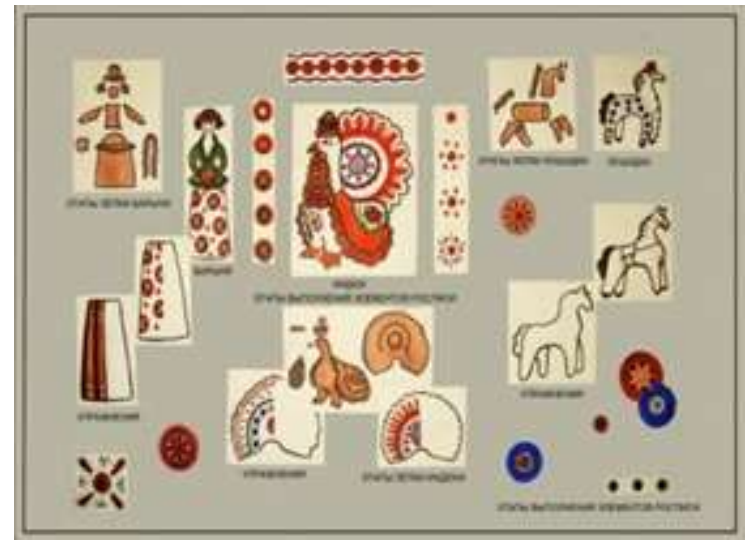

Figure 9. Khokhloma painting. Stage-bystage execution (Visual material)

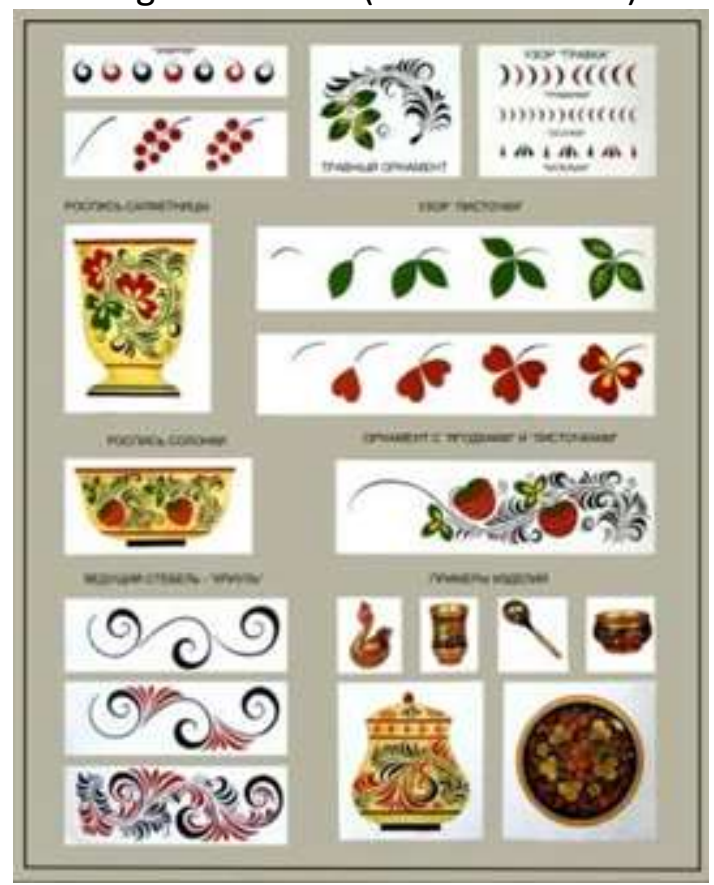

Figure 8. Filimonovo toy. Ways to perform sculpting (Visual material)

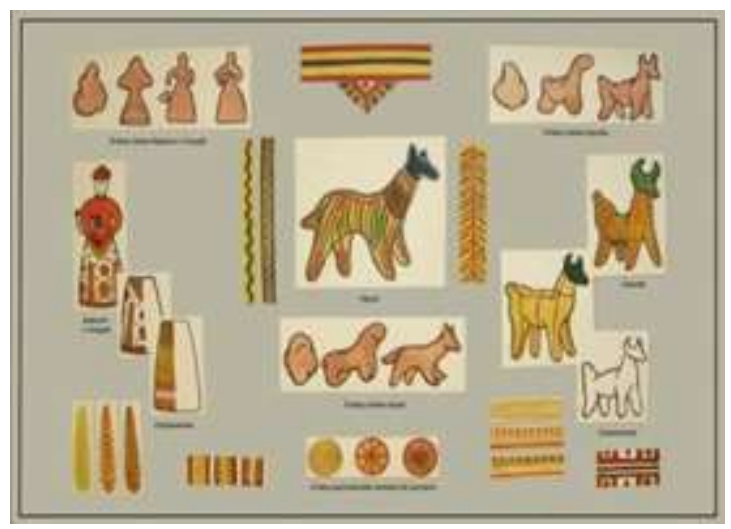

Figure 10. Permogorsk painting. Stage-bystage execution (Visual material)

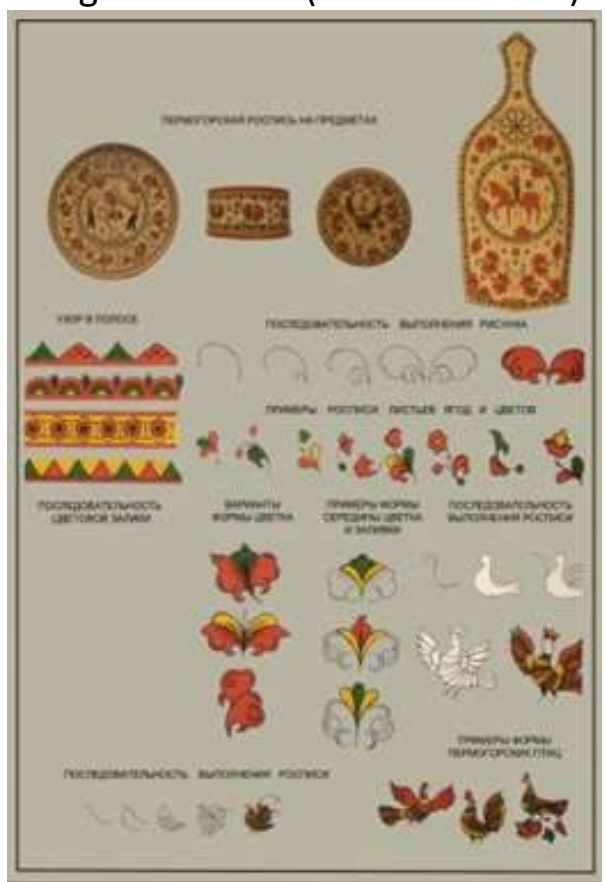

A teacher needs to remember that the educational material that is methodologically and competently made contributes to "the effective formation of the personal qualities of students, their creative abilities and art and aesthetic education" (Filippova, 2012, p. 29).

Teachers build the educational process based on modern psychological and pedagogical knowledge and improve the various nature of the assessment of educational results. The basis for the preservation and development of methodological support of additional education programs is, among other things, updating the competencies of teachers, loyalty to professional traditions and flexibility in solving professional problems, developed cooperation and interaction with colleagues, professional interpersonal environment and professional communications.

\section{RESULTS}

In modern society, the importance of the humanitarian aspirations of an individual and the tolerance of consciousness are recognized. Art education is important for the cultural and intellectual development of an individual and successful, full-fledged adaptation in modern society. 
"Art education, in all its diversity influences the moral, spiritual, aesthetic and intellectual development of an individual and is essential for every person for their successful and fulfilling life in modern society" (Koreshkov, 2015, p. 269).

In recent years, there has been an increase in the interest of children and their parents in obtaining additional education in the field of fine, decorative and applied arts, architecture and design. Project education is designed not only to integrate the knowledge, skills and competencies of an individual, but also to shape them for the active perception and use of changes in the world (Koreshkov, 2017). This fact is due to the development and the needs of the labor market, as well as the characteristics of the development of art and culture. Therefore, professions in this field are in demand and have a wide range.

A growing number of preschool children are involved in additional education programs.

The possibilities of organizations of additional education, preschool and general education organizations should be included in the process of attracting children from an early age to creativity in the field of visual art. According to L. A. Burovkina (2010c, pp. 78-79), "Classes of fine and decorative arts in institutions of additional education introduce students to art, help solve the problem of children's free time and unleash the creative potential of an individual".

The solution of the educational and upbringing tasks of preschool and school education leads to the formation of aesthetic representations of children. As noted by S. P. Roshchin (2013, p. 140), "The tasks facing the student can be defined as follows: learn to see and to portray".

The choice of a profession related to visual activity is not the main task of primary art education. First, the development of taste and aesthetic intuition is necessary; a child should learn spatial thinking and acquire a sense of color and form. "From the position of a person, the epicenter of self-identification shifts from the field of professional skills towards the development of the creative potential of self-realization and the active process of exploring the world" (Prishchepa et al., 2018, p. 394). All this is important for the harmonious development of personality.

\section{DISCUSSION}

To develop methodological recommendations, it is necessary to study and systematize best practices, innovative projects, new approaches to building education systems and programs, as well as exchange ideas and learning experience (Kholm, 2011).

The centuries-old history and unique achievements of Russian art education confirm the mission of organizations of additional education, whose activities are aimed at creating conditions for the spiritual development of children and youth, raising worthy citizens of the Russian state and determine the special responsibility of the state for maintaining a unique education system.

When implementing programs on art education, teachers need to allow children to choose various types of activities and creativity and help in the self-determination and self-development of the younger generation. A person must make every effort to consciously find a way to solve the problem (Harding, 1961).

\section{CONCLUSION}

The strategic goal of state policy in the field of education is to increase the availability of quality education that meets the requirements of the modern needs of society and every person (Roshchin, 2009). The development of education in the field of art and culture provides for individualization and focuses on the development of the personality of a child.

Preservation of the spiritual experience of humankind is the basis of the approach to education, the formation of culture and morality, the development of aesthetic and personal qualities of representatives of future generations. Confirming the hypothesis of the study, we can 
confidently say, "the trend of the interpenetration of the nature of art in different areas of artistic activity is relevant and deserves further research" (Prishchepa et al., 2019, pp. 356-357).

To organize support, preservation and development of the system for implementing additional general education programs in the field of fine, decorative and applied arts and folk crafts, it is necessary:

- to provide informational support and methodological support for the development and implementation of additional general and prevocational art programs based on the content of various types, techniques of fine, decorative and applied arts and folk crafts;

- to provide organizations of additional education with textbooks, teaching, educational, methodological and visual materials and other components of the methodological support of the educational process;

- to provide informational and methodological support in the development and implementation of programs of relevant modern continuing education programs for additional education teachers;

- to carry out comprehensive popularization and promotion of fine, decorative and applied arts and folk crafts through cultural and educational activities and competitive events;

- to systematically implement measures to identify, develop and support the visual art of folk art and culture, nurture and develop the personal success of children and familiarize them with the values of cultural heritage.

The result of the study is the identification of the possibilities and potential of teachers in the formation of a modern base of educational and methodological support in the system of additional education.

Authors' Contributions: Irina Vladimirovna Lovtsova: designed the study, prepared the plan, wrote the first draft of the manuscript and edited the final version. Lyudmila Aleksandrovna Burovkina: designed the study, prepared the plan, wrote the first draft of the manuscript and edited the final version. Anna Sergeevna Sheshko: designed the study, prepared the plan, wrote the first draft of the manuscript and edited the final version. All authors have read and approved the final version of the manuscript.

Ethics Approval: Not applicable.

Acknowledgments: Not applicable.

\section{REFERENCES}

Amirgazin, K.Zh. (1995). Nauchno-teoreticheskie osnovy i metodika obucheniia kazakhskomu dekorativno-prikladnomu iskusstvu $v$ obshcheobrazovatelnoi shkole [Scientific and Theoretical foundations and Methods of Teaching Kazakh Decorative and Applied Art in a Comprehensive School]: Ph.D. thesis. Moscow.

Arakelova, A.O. (2012). O realizatsii dopolnitelnykh predprofessionalnykh obshcheobrazovatelnykh programm $v$ oblasti iskusstv: sbornik materialov dlia detskikh shkol iskusstv [On the Implementation of Additional Prevocational Educational Programs in the Field of Arts: a Collection of Materials for Children's Art Schools]. Moscow: Russian Academy of music.

Arnheim, R. (2007). Iskusstvo i visualnoe vospriiatiie [Art and Visual Perception]. Moscow: Architecture-S.

Burovkina, L.A. (2010a). Kompleksnyi podkhod k obucheniiu shkolnikov dekorativno-prikladnomu iskusstvu v sisteme nepreryvnogo obrazovaniia [An Integrated Approach to Teaching Schoolchildren Arts and Crafts in the System of Continuing Education]. Vospitanie shkolnikov [Education of Schoolchildren], 4, 36-38.

Burovkina, L.A. (2010b). Narodnoe dekorativno-prikladnoe iskusstvo - osnova formirovaniia dukhovno-nravstvennoi kultury uchashchikhsia [Folk Arts and Crafts - the Basis for the Formation of Spiritual and Moral Culture of Students]. Srednee professionalnoe obrazovanie [Secondary Vocational Education], 4, 31-33.

Burovkina, L.A. (2010c). Teoretiko-metodologicheskie usloviia khudozhestvennogo obrazovaniia uchashchikhsia v uchrezhdeniiakh dopolnitelnogo obrazovaniia [Theoretical and Methodological Conditions of Art Education of Students in Institutions of Additional Education]: Ph.D. thesis. Moscow: MPGU [MSPU, Moscow State Pedagogical University]. 
Burovkina, L.A. (2011). Nauchno-metodologicheskie usloviia khudozhestvennogo obrazovaniia uchashchikhsia v uchrezhdeniiakh dopolnitelnogo obrazovaniia [Scientific and Methodological Conditions of Art Education of Students in Institutions of Additional Education]. Moscow: MGPU [MCU, Moscow City University].

Camargo, E. D. F., \& Givigi, R. C. N. (2021). The relationship between the school organization and the process of inclusion of an autistic student. Journal of Research and Knowledge Spreading, 2(1), e12354.

Christiansen, B. (1911). Filosofija iskusstva [The Philosophy of Art]. St. Petersburg: Shipovnik.

Feldshtein, D.I. (1994). Psikhologiia stanovleniia lichnosti [Psychology of Personality Formation]. Moscow: Mezhdunarodnaia pedagogicheskaia akademiia [International Pedagogical Academy].

Filippova, L.S. (2012). Esteticheskie i nauchnye obosnovaniia prirody vospriiatiia tsveta [The Aesthetic and Scientific Grounds for Explaining the Nature of Colour Perception]. Nauka i shkola [Science and School], 4, 163-165.

Harding, E. (1961). "What makes the symbol effective as a healing agent", in: G. Adler (ed.), Current Trends in Analytical Psychology. Proceedings of the first international congress for analytical psychology. London: Tavistock Publications.

Ignatiev, S.E. (2007). Zakonomernosti izobrazitelnoi deiatelnosti detei: uchebnoe posobie dlia vuzov [Patterns of the Pictorial Activity of Children: a Textbook for Universities]. Moscow: Academic Project; Fund "Mir".

Ilin, E.P. (2009). Psikhologiia tvorchestva, kreativnosti, odarennosti [Psychology of Creativity, giftedness]. St. Petersburg: Peter.

Kholm, S.-T. (2011). Innovatsionnaia tsep: v poiskakh nedostaiushchego zvena rossiiskoi innovatsionnoi sistemy [Innovation Chain: in Search of the Missing Link in the Russian Innovation System]. Bulletin Innovatsionnye Trendy [The Innovation Trends Newsletter], 1, 12-14.

Koreshkov, V.V. (1994). Formirovanie lichnosti uchashchikhsia v protsesse dekorativnoi deiatelnosti po khudozhestvenno-esteticheskoi organizatsii sredy [Formation of the Personality of Students in the Process of Decorative Activity on the Artistic and Aesthetic Organization of the Environment]: Ph.D. thesis. Moscow.

Koreshkov, V.V. (2015). Khudozhestvennoe obrazovanie dlia vsekh [Art Education for Everyone]. Sovremennye tendentsii razvitiia izobrazitelnogo, dekorativno-prikladnogo iskusstv i dizaina [Modern Tendencies of Fine, Decorative and Applied Art and Design], 13, 267-273.

Koreshkov, V.V. (2017). Proektnoe obrazovanie - osnova formirovaniia tvorcheskoi lichnosti [Project Education as a Basis in Forming a Creative Personality]. Mir nauki, kultury, obrazovaniia [The World of Science, Culture and Education], 3(64), 17-19.

Kuzin, V.S. (1998). Izobrazitelnoe iskusstvo i metodika ego prepodavaniia v shkole: uchebnik [Fine arts and the Methodology of Its Teaching at School: a Textbook]. Moscow: AGAR.

Likhachev, B.T. (1985). Teoriia esteticheskogo vospitaniia shkolnikov [Theory of Aesthetic Education of Schoolchildren]. Moscow: Prosveshcheniie [Education].

Lomov, S.P. (2011). Metodologiia khudozhestvennogo obrazovaniia: uchebnoe posobie [Methodology of Art Education: a Study Guide]. Moscow: MPGU [MSPU, Moscow State Pedagogical University.

Nalivaiko, N.V., Petrov, V.V. (2001). Innovatsionnoe obrazovanie v Rossii: vnedrenie ili izuchenie zarubezhnogo opyta? [Innovative Education in Russia: Introduction or Study of Foreign Experience?]. Filosofiia obrazovaniia [Philosophy of Education], 2, 62-70.

Prishchepa, A.A. (2013). Osnovy teorii i praktiki dizaina i dekorativno-prikladnogo iskusstva: uchebnoe posobie [Fundamentals of Theory and Practice of Design and Decorative and Applied Art: a Study Guide]. Rostov-on-Don: Pechatnaia Lavka [Printing Shop].

Prishchepa, A.A., Burovkina, L.A., Koreshkov, V.V. (2018). The Problem of Preparing Future Designers. International Journal of Engineering \& Technology, 7(4.38), 393-395.

Prishchepa, A.A., Burovkina, L.A., Maydibor, O.N. (2019). Children's creativity as a basis for the formation of artistic identity of Russia. Perspektivy nauki i obrazovania - Perspectives of Science and Education, 38(2): 342-360. DOI: 10.32744/pse.2019.2.26

Roshchin, S.P. (2009). Motivatsiia khudozhestvennogo obrazovaniia kak vazhneishaia zadacha metodiki prepodavaniia izobrazitelnogo iskusstva [Motivation of Art Education as the Most Important Task of the Teaching of Fine arts]. Vestnik Moskovskogo gosudarstvennogo universiteta kultury i iskusstv [Bulletin of Moscow State Institute of Culture], 4, 139143. 
Roshchin, S.P. (2010). Modelirovanie lichnostno-orientirovannogo obrazovatelnogo protsessa - vazhneishaia zadacha khudozhestvennoi pedagogiki [The Modeling of a Personality-oriented Educational Process is the Most Important Task of Artistic Pedagogy]. Vestnik Moskovskogo gosudarstvennogo universiteta kultury i iskusstv [Bulletin of Moscow State Institute of Culture], 3, 141-145.

Roshchin, S.P. (2013). Formirovanie professionalno-lichnostnykh potrebnostei khudozhnika-pedagoga [Formation of the Professional and Personal Needs of the Artist-teacher]. Moscow: MGPU [MCU, Moscow City University].

Rostovtsev, N.N. (2000). Metodika prepodavaniia izobrazitelnogo iskusstva v shkole: uchebnik dlia studentov KHGF [Methods of Teaching Fine arts at School: a Textbook for Students of the FGA (Faculty of Graphic Arts)]. Moscow: AGAR.

Shadrikov, V.D. (2002). Vvedenie v psikhologiiu: sposobnosti cheloveka [Introduction to Psychology: Human Abilities]. Moscow: Logos.

Souza, F. M. A., \& Ferreira, L. G. (2021). Contemporary Teacher education: contributions and learning. Journal of Research and Knowledge Spreading, 2(1), e11914.

Vanslov, V.V. (1989). Chto takoe iskusstvo [What is Art]. Moscow: Izobr. Iskusstvo [Fine arts].

Volkov, N.N. (2012). Kompozitsiia v zhivopisi [Composition in Painting]. Moscow: Kniga po Trebovaniiu [Book on Demand].

Zimniaia, I.A. (2003a). Kliuchevye kompetentsii - novaia paradigma rezultata obrazovaniia [Key Competencies - a New Paradigm of the Result of Education]. Vysshee obrazovanie segodnia [Higher Education Today], 5: 34-42.

Zimniaia, I.A. (2003b). Pedagogicheskaia psikhologiia: uchebnik dlia vuzov [Educational Psychology: a Textbook for Universities], 2nd Edn, enlarged, corrected and revised. Moscow: Logos.

Received: 11 May 2021 | Accepted: 12 June 2021 | Published: 23 June 2021

This is an Open Access article distributed under the terms of the Creative Commons Attribution License, which permits unrestricted use, distribution, and reproduction in any medium, provided the original work is properly cited. 